\title{
ЛЕГКОПЛАВКИЕ РАСПЛАВЫ С КАТИОНАМИ ПИРАЗОЛОНИЯ В ЭКСТРАКЦИОННО-ИНСТРУМЕНТАЛЬНЫХ МЕТОДАХ АНАЛИЗА
}

\author{
Темерев С.В., Петров Б.И., Петухов В.А. \\ ФГБОУ ВПО Алтайский государственный университет, Барнаул, Россия \\ temerev@mail.ru
}

DOI: 10.26902/ASFE-11_41

Антипирин, диантипирилметан, их производные проявили эффективность в аналитической практике титриметрии, фотометрии катионов, анионных форм азота, определения фенольного индекса поверхностных вод.

При этом управлять селективностью извлечения в органическую фазу можно изменяя анионный фон водной фазы. Разнообразие фазовых и экстракционных равновесий с протолитическим взаимодействием [1] протонированного основания с анионом-партнером кислоты позволили реализовать на практике экстракционно-инструментальные методы определения ионных форм элементов, азотистой кислоты, фенолов. Физико-химический анализ изотерм растворимости трехкомпонентных систем вода-производное пиразолонатвердая органическая кислота позволил выявить области двухфазного жидкостного расслаивания и реализовать на практике принципы «зеленой» химии, унифицировать подготовку in situ образцов к анализу концентратов веществ инструментальными методами.

Новые возможности инструментальной аналитической химии исследователи водных экосистем связывают с легкоплавкими расплавами, ионными жидкостями: производными имидазолия (гексафторфосфат 1-бутил-3-метилимидазолия), фосфония (тетрахлоралюминат тетрадецилфосфония) и $\mathrm{N}$-алкилпиридиния, которые в сочетании с апротонными растворителями или полимерной матрицей приобретают уникальные коэффициенты диффузии и другие свойства. При всех преимуществах подобных систем для экстракции ограничивают затратный препаративный синтез ИЖ, а также неопределенность роли воды в такого рода ионных ассоциатах.

Экстракция веществ системах без органического растворителя с единственным жидким компонентом и концентрирование веществ легкоплавкими расплавами с катионами пиразолония расширяют возможности инструментальных методов. Антипирин, диантипирилметан, их производные и органические кислоты не токсичные, твердые порошкообразные вещества, обеспечивают удовлетворительнное извлечение микроколичеств нормируемых токсикантов из природных объектов, позволяют регистрировать полезный сигнал абсорбции (молекулярной, атомной) и предельные диффузионные токи микроэлементов на границе индикаторный электрод - органический гидрато-сольватный

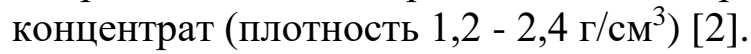

Аналоги ИЖ в виде солей пиразолония можно получить, используя малорастворимые в воде алкилированные производные диантипирилметана, которые применяли ранее в трехфазной и для соосаждения. Особой привлекательностью отличаются легкоплавкие расплавы солей: дисульфоссалицилат гексилдиантипирилметания $\mathrm{t}_{\text {пл. }}=(56 \pm 1)^{\circ} \mathrm{C}$, ацетилсалицилат антипириния с $\mathrm{t}_{\text {пл. }}=85^{\circ} \mathrm{C}$ количественно извлекают ртуть (II), реализуется групповое концентрирование жестких катионов из кислых хлоридных растворов [3].

Замена жесткого кислорода на более мягкий донор - серу позволил расширить эффективность извлечения до ряда халькофильных элементов. Эффективность систем с тиопирином показана на реальных образцах снега и воды в сочетании с атомной абсорбцией и вольтамперометрией [4].

\section{Список литературь}

1. Б.И. Петров, А.Е.Леснов, С.А.Денисова //ЖАХ, 2015. Т.70, №6, С.563-576.

2. О.Б.Станкевич, С.В.Темерев//Аналитика Сибири и Дальнего Востока, 2016. С. 188.

3. С.В.Темерев, Б.И. Петров, Ю.П.Савакова//ЖАХ, 2017. Т.72, №8, С. 1-6.

4. С.В.Темерев и др.// Аналитика Сибири и Дальнего Востока, 2016. С. 191. 